\title{
Sosial mediada kiber zorakılıq və intihar təbliğatı
}

\author{
İlahə Cəbrayılova \\ AMEA İnformasiya Texnologiyaları İnstitutu, Bakı, Azərbaycan \\ ilahe.jabrailovalgmail.com
}

\begin{abstract}
Xülas - Məqalədə əsrin bəlası sayılan kiber zorakılıqlar, onların yol açdığı fəsadlar və səbəb olduğu intiharlar araşdırılır. Həmçinin kiber zorakılığa vadar edən səbəblər, gənclərin bu təhlükələrdən sığortalanması üçün tətbiq olunan beynəlxalq təcrübə təhlil olunur.
\end{abstract}

Açar sözlar- sosial media, kiber zorakılıq, intihar, kiber zərərçəkmiş, kiber təcavüz

\section{GİRIŞ}

İnformasiya kommunikasiya texnologiyaları, xüsusilə də internet məlumat əldə etmə, saxlama və paylaşma funksiyaları ilə həyatımızın vacib amilinə çevrilib. Lakin faydaları ilə birgə texnologiyadan bəd niyyətlə istifadə nəticəsində bir sıra problemlər də ortaya çıxır. Həyatımıza gətirdiyi rahatlıqla yanaş1 kompüter, mobil telefon kimi informasiya texnologiyaları insanlara zərər vermək məqsədilə də istifadə edilməkdədir [1]. Bunların da başında kiber zorakılıq gəlir. Kiber zorakılıq informasiya texnologiyalarından istifadə etməklə bir fərdə və ya qrupa, fiziki və ya hüquqi şəxsə qarşı edilən texniki və ya mənəvi zərər vermə davranışlarının ümumi halı kimi təsvir edilir. Eyni zamanda "elektron mətn vasitəsi ilə qəsdən və təkrarən verilən zərər" olaraq da adlandirılır [2].

Kiber zorakılıq hallarının və qurbanlarının sayı gündəngünə artmaqdadır. Bu cür hallar son vaxtlar daha çox intihar səbəbi olaraq göstərilir. Hətta kiber zorakılığı əsrin bəlası adlandırırlar. Bu məqsədlə sosial mediada sürətlə yayılan və gənclərin həyatı üçün ciddi təhlükə sayılan kiber təcavüz: təhdid, qeyri-qanuni yolla əldə edilən şəxsi məlumatların şantaj aləti kimi istifadə edilməsi və intihar oyunları tədqiq edilir.

\section{SOSİAL MEDİADA KİBER ZORAKILIQ PROBLEMLORI}

Mütəxəssislərə görə kiber zorakılı̆̆ın nəticəsi əksər hallarda mənfi, hətta məhvedici ola bilər. Kiber təcavüzə məruz qalan uşaqlar və yeniyetmələr bir çox cəhətdən mənfi təsirlənirlər. Onlarda sosial münasibətlərdə pozulma, bədbinlik, qəzəb, narahatlıq, akademik uğursuzluq, dərsə davamsızlıq, təklik, depressiya və intihar halları kimi ciddi problemlər müşahidə edilməkdədir [3]. Sosial-iqtisadi vəziyyəti aşağı olan təbəqənin yaşadığı ərazilərdə təhsil alan şagirdlər, bu cür hadisələrdə orta və yuxarı təbəqənin şagirdlərinə nisbətən psixoloji cəhətdən daha çox sarsılır və travma simptomları daşıyırlar [4]. Sosial mediada xarici görünüşlərini gülüş obyektinə çevirən insanların təzyiqləri nəticəsində onlarla gəncin həyatlarına son verdiyi qeydəalınıb.
Yeniyetməlik dövrünü yaşayan şəxsin hər hansı bir məşğuliyyəti yoxdursa, dost tapmaqda, insanlarla münasibətdə çətinlik çəkirsə, özünü ən rahat ifadə edə biləcəyi, heç kimin onun real kimliyini bilmədiyi bir virtual mühitdə "istədiyini etmək azadlığı" fikri onu cəlb edir. Psixoloqların fikrinə görə, onlar bu cür oyunlar sayəsində varlığını sübut etmə və dəyərli olduğunu hiss etmə duyğusuna qapilırlar: "Ailələr mütləq uşaqların oynadığı, girdiyi saytları izləməlidir. Yoxsa sosial mediada "qəhrəman" olmağa çalışan uşaqların sonu intiharla nəticələnir" [5].

\section{KİBER ZORAKILIQ İSTİQAMӘTINDə APARILAN ARAŞDIRMALAR}

Azyaşlıların və yeniyetmolərin vaxtının çoxu kompüter qarşısında keçirsə, narahatlığa ciddi əsas var. 2017-ci ildə Böyük Britaniya məktəb və kolleclərində 12-20 yaş arası on mindən çox gəncin arasında araşdırma aparılıb və hesabat hazırlanıb [6]. Gənclərin başqalarına qarşı göstərdiyi təzyiqin, zorakılığın səbəbləri araşdırılıb. Hesabat aşağıdakı məsələləri əhatə edir:

- Böyük Britaniyada baş verən zorakılıq statistikası;

- Zorakılıq motivasiyası;

- Zorakılı̆̆ın mahiyyəti;

- Zorakılığın təsiri;

- Başqalarını təhqir etməyə meylli gənclərin sayı;

- İnternetdə kiber hücum və istismarın miqyası və coğrafiyası;

- Rəqəmsal bir dünyada böyümək nədir?;

- Sosial media meylləri, zorakılıq və asılılıq;

- Tövsiyələr;

- Real hekayələr və təcrübə.

Hesabatda həmçinin məktəblər, kolleclər, praktikantlar, valideynlər (qəyyumlar) və gənclər üçün təklif və tövsiyələr yer alır [6].

“The Telegraph”ın paylaşdığı tədqiqatın nəticələrinə görə, İngiltərədə sosial media istifadəçilərinin təqribən 59\%-nin sosial şəbəkədən istifadə edən 10 yaşa qədər, 43\%-nin isə tanımadığı şəxslərlə mesajlaşan 12 yaşına qədər uşaqlar olduğu bildirilir. "Facebook"da hesab açmaq üçün ən aşağı yaş limiti 13-dür, bu sosial şəbəkədə qeydiyyatdan keçərkən 8-16 yaş arası uşaqların 52\%-i yaşını olduğundan daha böyük yazır. Mobil mesajlaşma proqramı "Whatsapp" istifadəçilərinin ən azı 16 yaşında olmasını tələb edir, lakin araşdırmaya görə yaşı 


\section{"İnformasiya tohlükssizliyinin aktual problemlori" \\ III respublika elmi-praktiki seminarı, 08 dekabr 2017-ci il}

16-dan aşağı olan uşaqların 40\%-i bu tətbiqi əlavədən istifadə etməkdədir. Minimum yaş həddi 13 olan mesajlaşma xidməti "Snapchat"1 isə azyaşlıların 11\%-i təşkil edir. Bu yaşlarda olan uşaqlar sosial mediada saxta bir profil açmaqla, ilk dəfə pornoqrafik məzmunlu foto-video materiallarla qarşılaşır, "Twitter" və "Whatsapp"da tanımadıqları insanlarla əlaqə qururlar [7].

Xüsusilə yeniyetmələr üzərindəki təsirlərinə diqqət çəkmək üçün İstanbulda orta məktəblərin 5, 6, 7 və 8-ci siniflərindəki 4291 şagird, 916 müəllim və 727 rəhbər arasında araşdırma aparılıb və maraqlı nəticələr əldə edilib. Araşdırma nəticəsində məlum olub ki, şagirdlərin $26.52 \%$-i kiber zorakılığa məruz qalır. Şagirdlərin 9.42\%-nin kiber hücumlar edən, 11.79\%-nin bu hadisələrdə kiber zərərçəkmiş tərəf və $5.31 \%$-nin isə həm kiber cinayətkar, həm də kiber zərərçəkmiş olduqları məlum olub. Q1z şagirdlərin oğlanlara nisbətən daha az kiber hücumlar törətdiyi, həmçinin daha az kiber təcavüzə məruz qaldıqları molum olub [5].

Kompüter, mobil telefon, e-mail kimi vasitələrdən insanları təhdid etmək, alçaltmaq, pornoqrafik məlumatlar ehtiva edən şəkil və mesajlar göndərmək, başqalarına zərər vermək məqsədilə istifadə etmək məktəblərdə, gənclər arasında yayılan ciddi bir təhlükə hesab olunur. Oksər hallarda kiber zorakılığa məruz qalan şəxslər valideynlərindən və ya sosial çevrənin qınağına məruz qalmaqdan çəkindiyindən bunu gizli saxlamağ üstün tuturlar. Kiber zorakılıq və onunla mübarizə yollarını tədqiq edən mütəxəssislər son dərəcə həssas olan bu mövzunun araşdırılmasının çətin olduğunu bildirirlər [8].

\section{KİBER ZORAKILIĞIN SəBӘB OLDUĞU INTIIHARLAR}

Valideynlərin uşaqların oynadıqları oyunlardan, internetdə ünsiyyət qurduqları şəxslərdən xəbərsiz olmaları bir sıra faciələrə yol açır. Xüsusən q1z uşaqlarının valideynlərindən çəkindikləri üçün üzləşdikləri problemləri onlardan gizlətmələri sonda xoşagəlməz hallarla nəticələnir.

2012-ci ildə Avstraliyada yaşayan türkiyəli gənc Şeniz Erkanın sosial media hesablarının oğurlanması və qızın adından başqalarına mesajlar yazılması nəticəsində onun mobil telefonuna təhdid və təzyiq mesajları gəlməyə başlayıb. Bunlara dözə bilməyən gənc q1z özünü qatarın altına ataraq intihar edib. Bu hadisədən sonra Avstraliynanın baş naziri Julia Gillard hökumətin dövlət sistemləri üçün qurduğu kiber müdafiə sistemini bu cür virtual hücumlara qarşı mübarizədə də tətbiq etməyi tapşırıb. Amerikada bir ildən artıq kiber təzyiqlərə məruz qalan 12 yaşlı Rebeka Sedvik özünü yüksək bir yerdən ataraq həyatına son qoyub. Polis q1zın ölümünü araşdırarkən ona gələn mesajlar arasında "ölməlisən”, "niyə özünü öldürmürsən?" kimi mesajlara rast gəlib. Amanda Todd 7 sentyabr 2012-ci ildə "Youtube" səhifəsində 9 dəqiqəlik «Mənim hekayəm: mübarizə, zorakılıq, intihar, özünə zərər vermə» adlı video yayımlayıb. Bu videoda mərzu qaldığı kiber təcavüzü və həyatında baş verən dəyişiklikləri kağızlar üzərinə yazdığı yazılarla izah edir. Videodan bir ay sonra isə evində özünü asaraq həyatına son verib.
Uşaqlar üçün kiber təhdidin digər yolu oynadiqları oyunlardır. Son bir il orzindo sosial mediada oynanılan bir oyun dünyanın əsas gündəmini təşkil etməkdədir. "Blue Whale Challenge" olaraq da tanınan və bir çox ölkədə oynanıldığ bildirilən, həssas yeniyetmələri hədəf alan, intihara səsləyən "Mavi Balina" internet oyununun Rusiyada 130 yeniyetmənin intiharı ilə əlaqəli olduğu iddia edilir [9]. İlk dəfə bu oyun 2013-cü ildə "Vkontakte" sosial şəbəkəsində yaradılan "ölüm qrupu" adlı bir qrup vasitəsilə yayılmağa başladı. "Тихий дом", “Море китов", “Млечный путь", "F57” kimi digər adlarla da tanınan oyun 50 bənddən ibarət olur, son bənddə oyunçunun intihar etməsi tələb edilir. Oyun oxuduğu universitetdən uzaqlaşdırılan Psixologiya fakültəsinin tələbəsi Rusiya vətəndaşı Filip Budeykin tərəfindən yazılıb. 16 gənc qızı ölümə sürükləməkdə ittiham olunan və 2016-c1 ilin noyabr ayında həbs olunan 21 yaşlı Budeykin məhkəmədə törətdiyi cinayəti etiraf edib. O oyunun qurbanlarını "bioloji tullantılar" adlandıraraq, cəmiyyətdə "təmizlik" etdiyini söyləyib [10].

Oyunu oynamaq istəyən şəxslərə admin adlandırılan internet piratları tərəfindən virus tərkibli bir link göndərilir. Şəxsi məlumatları "Phishing" üsulu ilə (onlayn bir hesabın qanuni şirkət kimi göstərilərək maliyyə məlumatlarını saxtalaşdırması) oğurlanan gənclər yaxın çevrələrindəki şəxslərlə, ailələriylə bağlı hədə-qorxu, şantaj ve kiber zorakılığa məruz qalır. Bundan sonra "oyunçu"dan verilən təlimatların yerinə yetirilməsi istənilir. Qəsdən gecə saatlarında tələb edilən müxtəlif və dəhşətverici tapşırıqlarla oyuna qatılanların psixi sağlamlıqlarını pozmaq nəzərdə tutulur. 50 tapşırıqdan ibarət olan və 50 gün müddətində davam edən dialoqun sonunda oyunu oynayan şəxslərə yanlış qərar qəbul edən, dəyərsiz insan olduqları hissi aşılanır və son tapşırıq olaraq intihara təşviq edilir. Həmin əlli mərhələdə uşaqların qorxulu filmlər izləməsindən özünə zərər verməsinə qədər ağlasığmaz bəndlər yer alır. Tapşırıqları yerinə yetirib oyunu bitirməyən istifadəçilərə "öl, onsuz da yenidən doğulacaqsan" düşüncəsi təlqin edilir. Oyunun səbəb olduğu ilk intihar faktı 2015-ci ildə qeydə alınıb. İki türk gəncinin intiharı da sözügedən oyunla əlaqələndirilir. "Mavi Balina" oyunundan xilas olanlar da var. Onların dediklərinə görə, "oyunu tamamlamasan anan, ailən öləcək" kimi hədə-qorxularla gəncləri qorxunc hərəkətlərə məcbur edirlər [10].

Dünya mətbuatının diqqətini bu məsələyə yönəldən səbəb 15 yaşlı Yuliya Konstantinovna və 16 yaşlı rəfiqəsi Veronika Volkova oyunun nəticəsində həyatlarına son verməsi olub. Q1zlardan biri yüksək mərtəbəli binadan özünü ataraq intihar edib. Ölümündən əvvəl hər iki qiz sosial şəbəkə profillərində "Son", "Hisslər itib" kimi sözlər yazıblar [11]. Ancaq Budeykinin sosial mediada başlatdığı "Blue Whale Challenge" təkcə Rusiya ilə məhdudlaşmır. Bu "oyun"un artıq dünya miqyasında da yayıldığı məlum olub. Almaniyada yaşayan 14 yaşlı türk Furkan Şən isə oyunun son qurbanı olaraq bilinir [10].

Böyük Britaniya polisi, eləcə də Almanya, ABŞ, Fransadak1 məktəb rəhbərləri bu problemə dair valideynlərə xəbərdarlıq etməyə başlayıb. İnternetdə oynanılan oyun Q1rğızıstan, Ukrayna və Rusiyada iki il ərzində 150 gəncin ölümünə səbəb olub. Artıq Avropa Birliyi bununla bağlı 


\section{"Informasiya tohlükosizliyinin aktual problemlori" \\ III respublika elmi-praktiki seminarl, 08 dekabr 2017-ci il}

həyəcan təbili çalır. Beynəlxalq Polis Təşkilatı (İnterpol) bu oyunla bağlı Belçikaya xəbərdarlıq göndərib. Belçika Federal Prokurorluğu polisin də bu cür hadisələrə diqqətli yanaşmasını tələb edib [11]. Artıq Qazaxıstanda "ölüm sektası" adlanan təhlükəli oyunlara giriş qadağan edilib. Paytaxt Astanada ilin əvvəlindən bu günə qədər 63 uşaq bu oyunlarda iştirak etmək üçün qeydiyyatdan keçib və 15 uşaq müxtəlif xəsarətlər alıb. Ötən il isə 16 uşaq "ölüm sektası" adlanan bu oyunlara görə dünyasını dəyişib. Karaqanda vilayətinin sakini, 19 yaşlı Qalina Sibiryakova fevralın 7-də ölü halda tapılıb. Deyilənə görə, o da bu oyun qrupunun üzvü imiş və daim evdə kiminləsə "Skype" vasitəsilə əlaqə saxlayırmış. Yanvarın 29. da özünü yaşadığı binanın 5-ci mərtəbəsindən atan 7 yaşlı Temirtaunun valideynlərini qorumaq üçün bu addımı atdığı deyilir. "Ölüm sektası"na daxil olan oyunlardan "Blue whale" artıq Azərbaycanda da geniş yayılıb [12].

\section{KİBER ZORAKILIĞIN TӘHLÜKӘLӘRINDӘN QORUNMAĞIN YOLLARI}

Böyük Britaniyanın The Times qəzetinin verdiyi məlumata görə, "Facebook" və “Instagram”1n “özünə qəsd”lə bağl kontentlərə məhdudiyyət qoyulması istiqamətində gördüyü tədbirlər qeyri-kafidir. Qəzet, oxşar məzmunun "Youtube" vasitəsilə də yayıldı̆̆ını bildirib, ancaq yazılan xəbərlərdən sonra video paylaşma saytında həmin məzmunlar silinməyə başlayıb. The Times hələ İngiltərədə internet oyunlarının səbəb olduğu bir ölümün qeydə alınmadığını yazsa da, bəzi məktəblərdə problemin ailələrə bildirildiyi və bu barədə xəbərdarlıq edildiyi açıqlanır [7].

Psixoloqlar dünyada əskər uşaqların kompüter aludəçisi olduğunu və tanımadığ 1 insanlarla ünsiyyətə girdiyini, nəticədə xoşagəlməz hadisələrin yaşandığını deyirlər. Buna görə də, evdəki kompüterin nəzarət altında istifadə edilməsində ailələrin üzərinə böyük məsuliyyət düşür. Uşaqların təhlükəsiz şəraitdə internetdən istifadəsini təmin etmək üçün edilən təkliflərdən bəziləri aşağıdakılardır:

- Uşağa nəzarətsiz kompüter verməyin;

- Interneti tamamilə qadağan etməyin;

- İnternetdəki münasibətlər və virtual həyat haqqinda məlumatlar öyrənib uşaqlarınızla paylaşın;

- Kompüteri uşağınızın otağına deyil, salonda və ya qonaq otağında quraşdırın;

- İnternetdən növbə ilə istifadə edin. Beləliklə, uşağınızın həddindən artıq istifadəsinin qarşısını ala, həm də onu mənfi təsirlərdən sığortalamış olarsınız;

- Uşağınızla münasibətinizə önəm verin. İnternetdə hər hansı bir problemlə qarşılaşdığında çəkinmədən sizə deyə biləcəyini bildirin;

- İnternetdən istifadə mövzusunda uşağınıza yaxşı örnək olmağa çalışın.

Qadınlara qarşı kiber zorakılığa meylli, onlara münasibət təklif edən və bəzən də onları təhdid edən insanlara qarşı hadisələrə çox sıx rast gəlirik. Bu hadisələri şəxsən yaşamış və bunu problem kimi görən 15 yaşındakı bir proqramçı q1z mükəmməl ideya üzərində çalışıb. Amerikalı Trişa Prabhu adlı qızın yaşadığ 1 əyalətdə bu tipli halların nəticəsində - kiber zorakılıq və kiber təhdidlərdən sonra 11 nəfər gənc q1z intihar etmişdi. Bütün bu problemləri göz önünə gətirən gənc q1z bu mövzu ilə bağlı tətbiqi proqram hazırlayıb. "ReThink" adlanan tətbiqi əlavənin məqsədi pis niyyətlə yazılan mesajların qarşısını almaqdır. Trişa 2013-cü ildə oxuduğu bir məqalədən sonra bu fikrə düşüb. Məqalədə bunlar qeyd olunmuşdu: "Yeniyetmə beyni əyləci olmayan maşın kimidir". Məhz bu sitatdan sonra sadalanan mənfi halların qarşısını almağı hədəf seçən bu gənc q1z, məqsədinə böyük ölçüdə nail olub. "ReThink"-in işləmə mexanizmi sadədir: sizi təhqir edən, müxtəlif təkliflər edən və sizi kiber zorakılığa məruz qoyacaq mesajları müəyyən edərək, mesajı açmamış sizə dərhal bildiriş göndərərək xəbərdarlıq edir. 1500 yeniyetmə üzərində test edilon bu tətbiq $93 \%$ effektli olub və hal hazırda təkmilləşdirilir [13].

Uşaqların internet asılılığı ilə bağlı problemlərin səviyyəsini öyrənmək üçün müxtəlif üsullar var. Bunlardan ən geniş yayılmışı Kimberli Yanqın metodikasıdır: "Həmin metodikaya əsasən, uşağa internetdən istifadə ilə bağlı 20 psixoloji sual verilir vo verdiyi cavablar əsasında onun internet asılılığının səviyyəsi qiymətləndirilir. Müəyyən bir hədd var, o həddi keçmək risk səviyyəsi sayılır. 2012-ci ildə yerli tələbələr arasında bu metodika tətbiq edilib və azərbaycanlı tələbələrin bu təhlükəli həddi keçdiyi məlum olub. Dünyada bir çox klinikalarda bu metoddan istifadə edilsə də, Azərbaycanda hələ ki, tətbiq olunmur. Bizdə əsasən həkimlərə, psixoloqlara edilən müraciətlər əsasında uşaqlar arasındakı internet asılılığı probleminin səviyyəsini bilmək olar" [14].

\section{NӘTİCə}

Ekspertlər günümüzdə modern hayatın və rəqəmsallaşmanın təsiriylə uşaqların və gənclərin internetdə keçirdiyi vaxtın artdığına diqqət çəkir. Uşaqların sosial mediada və internet mühitində bu cür hiylələrə aldanmaması üçün valideynlər tərəfindən izlənilməsini, xüsusilə oynadıqları oyunların seçimində valideynlərin uşaqlarla birgə iştirak etmələrini tövsiyə edir. Oyunların uşaqların yaşına uyğun olması vacibdir. İnternetdə tanımadığ1 şəxslərə qarş1 şübhəylə yanaşılmasını və bu şəxslərin təhlükəli ola bildikləri, kiber zorakılığın mahiyyəti uşaqlara mütləq izah edilməlidir. Lazım gəldikdə, valideynlər professional şəxslərdən yardım almalı, uşaqları sosial fəaliyyətlərə yönləndirməli və sosial şəbəkələrdə onlarla dostluq edərək atdığı addımlardan xəbərdar olmalıdırlar.

Bundan əlavə, valideynlər kompüterdə bir neçə sadə əməliyyatları yerinə yetirməklə övladlarını lazımsız informasiya, pornoqrafik şəkil və videolardan qoruya bilərlər. İstənilən "browser"də və kompüterlərdə DNS kodlarında dəyişiklik etməklə bu cür kontentli saytlara girişi bağlaya bilərsiniz [15]. Və ya internetdə axtarışlar zamanı şəkillər və videolar bölməsində uşaqlarınızın qarşısına bu növ məlumatların çıxmaması üçün "Google" tənzimləmələrindən təhlükəsiz axtarışı aktivləşdirə bilərsiniz. Alternativ üsullar da mövcuddur ki, bəzi proqramlar və əlavələri kompüterə 
yükləyib aktivləşdirməklə arzuolunmaz saytlara girişi qadağan etmək mümkündür.

Ölkəmizdə isə zorakılıq davranışlarının qarşısını almaq və zərərçəkmiş gənclərə yardımla bağlı hələ ki, heç bir layihə mövcud deyil. Sosial medianın getdikcə artan təhlükələrini nəzərə alsaq, böyüklərin, müəllimlərin, valideynlərin üzərinə böyük məsuliyyət düşür. Bu istiqamətdə beynəlxalq təcrübənin mənimsənilməsi, orta məktəblərdə maarifləndirmə işlərinin aparılması, valideynlərin və gənclərin xəbərdar edilməsi son dərəcə vacibdir. Bununla bağlı televiziyada sosial çarxların nümayiși, internet mühitdə real təhlükələr, kiber cinayət, kiber zorakılıq mövzusunda verilişlərin hazırlanması da insanların məlumatlandırılması baxımından məqsədəuyğun olardı.

\section{ӘDӘВIYYYAT}

[1] C. S. Bhat, Cyber Bullying: "Overview and Strategies for Schoo Counsellors, Guidance Officers, and All School Personnel”. Australian Journal of Guidance and Counselling, 2008. p. 53-66.

[2] S. Hinduja, J.W. Patchin, "Cyberbullying: An Exploratory Analysis Of Factors Related to Offending and Victimization". Deviant Behavior, 2008. p. 129-136.

[3] M. A. Campbell, "Cyber bullying and young people: Treatment principles not simplistic advice", 2007.

[4] D. J. Flannery, K. L. Wester, M. I. Singer, "Impact of exposure to violence in school on child and adolescent mental health and behavior". Journal of Community Psychology, 2004. p. 559-573.

[5] B. Dorukoğlu, Sosyal Medya ve Çocuklar http://dijitalmedyavecocuk.bilgi.edu.tr/2017/04/06/sosyal-medya-vecocuklar/
[6] The Annual Bullying Survey, Ditch the Label. UK, June, 2017. p. 40. https://www.ditchthelabel.org/wp-content/uploads/2017/07/TheAnnual-Bullying-Survey-2017-1.pdf

[7] http://www.bbc.com/turkce/39892509

[8] E. Yaman, Y. Eroğlu, A. Peker, "Okul Zorbalığı ve Siber Zorbalık". İstanbul: Kaknüs Yayınları, 2011.

[9] https://en.wikipedia.org/wiki/Blue_Whale_(game)

[10] http://www.sozcu.com.tr/2017/gundem/mavi-balina-oyunu-cocuklarinasil-olduruyor-bu-oyuna-dikkat-2011441/

[11] https://www.unilad.co.uk/crime/the-disturbing-online-game-linkedto-130-suicides/

[12] http://publika.az/news/maraqlidunyasi/197783.html

[13] https://technote.az/az/15-yasndak-qzdan-kiber-tecavzn-qarssn-alacaqtetbiq

[14] http://www.mia.az/w256372/.../

[15] https://technote.az/az/pornoqrafik-saytlara-giris-qadagasi-qoymaq

\section{CYBERBULLYING AND SUICIDE ON SOCIAL MEDIA}

Ilaha G. Jabrayilova

Institute of Information Technology of ANAS, Baku, Azerbaijan ilahe.jabrailova@gmail.com

Abstract - The article examines cyber violence, which is the scourge of the century, the suicides and complications they caused. Also, the reasons of cyberbylling, international experience in cyber security is analyzed to insure young people from these dangers.

Keywords - social media, cyberbullying, suicide, cyber attack, cyber victim, cyber harassment 